\title{
NET BENEFITS OF URBAN SLUMS REDEVELOPMENT POLICIES ON THE VALUE OF ADJACENT RESIDENTIAL PROPERTY
}

\author{
Touseef HUSSAIN, Zou WEI \\ College of Public Administration, Nanjing Agricultural University, 210095 Nanjing, China \\ Received 06 May 2020; accepted 20 January 2021
}

\begin{abstract}
Over time, the government of Pakistan introduced several strategies to deal with the issue of slums in its capital city, Islamabad. Contrary to the traditional strategies that primarily focus on the tenure security of occupants, the strategy of slum redevelopment is more composite. It involves the up-gradation of slums in their existing sites as well as the demolition of slums from the posh areas. The present study is first to empirically investigates the outcomes of the slums redevelopment policies on the value of adjacent residential properties. Using a rental valuation based hedonic price model, the study examined the spillover effects of an urban slum up-gradation and eviction projects on the nearby housing values. The results show that the redevelopment of slums reduces the adverse effects on residential value. It is essential for the urban planners to cautiously include the slum redevelopment projects spillover effects on the adjacent property value in different geographical locations, to maximize the net positive effects of improvements on the neighborhood.
\end{abstract}

Keywords: slums, up-gradation, demolition, hedonic price model, property value, Pakistan.

\section{Introduction}

The fast-growing urbanization has consistently been a distinctive characteristic of the process of development and has almost been continuously accompanying by the similarly fast growth of informal settlements, squatter settlements, slums, and other uncontrolled settlements (Asian Development Bank and Inter-American Development Bank, 2014; Malik et al., 2020). Slums had always been considered an essential component of cities globally since the outgrowth of urbanization and cities of Pakistan is not an exceptional case; the slums are locally known as Katchi abadis. Governments around the world have recognized the issue of slums as many economic, social, and environmental problems are linked with the creation of slums (Nijman, 2008). In Pakistan, the government has taken several steps to resolve the issue of slums. Over time, the policies of the state have gone through paradigm shifts from emphatic demolition to the provision of housing units to the urban poor. Currently, in Islamabad, there are almost 34 slums out of which the government owns only ten slums as authorized and takes responsibility for the development of infrastructure (Hussain et al., 2019). The government rehabilitated the slums using the three concepts application of Urban Renewal, which includes slums Up-gradation at the present site in existing form, Slums relocation to the Model Urban Shelter Project (MUSP), and Slums Up-gradation at the site in the form of planned plots. In comparison, the rest of the slum settlements are unauthorized or illegal and faced eviction or demolition over time (Malik et al., 2020). The current study attempts to investigate the outcomes of several government initiatives for the improvement of urban infrastructure and the redevelopment of slum areas.

One of the critical arguments about adopting urban redevelopment is that it brings positive externalities to the real estate in the neighborhood (Newell, 2010). Furthermore, redevelopment supports the improvement process of the urban environment, boosts the property values in the locality, and improves life standard, public security, and overall image of the city. Supporters of urban renewal believe that redevelopment results in a win-win situation for all the stakeholders by creating positive externalities beyond the borders (Newell, 2010). Moreover, they consider redevelopment as an essential tool for bringing positive externalities to augment the values of the property (such as land and building) for the owners of the property, whereas increasing the chances for authorities in raising the tax base. A few studies also depict that redevelopment schemes on a large scale enhance the property values in the neighborhood, such as (De Sousa et al.,

*Corresponding author. E-mail: zw@njau.edu.cn

Copyright (C) 2021 The Author(s). Published by Vilnius Gediminas Technical University

This is an Open Access article distributed under the terms of the Creative Commons Attribution License (https://creativecommons.org/licenses/by/4.0/), which permits unrestricted use, distribution, and reproduction in any medium, provided the original author and source are credited. 
2009). Globally, a large number of studies shed light on the crucial relationship between the quality and values of the property. Amenities brings positive effects on the value surrounding properties such as a landmark, parks, green places (Zawadzki et al., 2017). In contrast, disamenities like landfill sites, informal slums settlements, incineration plant sites, and contaminated sites (Zabel \& Guignet, 2012) adversely affect the neighborhood property prices.

The present hedonic study is the first to examine the impacts of urban slums' up-gradation and eviction on housing prices in Islamabad, Pakistan. Furthermore, a conceptual framework is developed in which the hedonic modeling is incorporated into a planning support methodology to simulate the economic impacts of urban slums up-gradation and eviction projects. This study will make a significant contribution to future policymaking issues regarding urban slum settlements redevelopment matters. Policymaking bodies can employ this decision support methodology for the estimation of economic impacts of various scenarios related to urban slum's up-gradation and eviction. Quantifying the benefits of urban slum development will also encourage more significant investment in the projects of urban slum redevelopment and consequently implement sustainable urbanization.

\section{Literature review}

The residential dwelling unit is a set of multiple features, and each attribute influences the value of the property (Rosen, 1974). Attributes that affect the price of residential property can be categorized into three leading kinds, such as locational, environmental, and structural attributes. The physical characteristics of the building are known as structural attributes, which define property structure such as building age, floor size, number of bathrooms, size of the building, number of bedrooms, parking facilities, and lawn (Xiao, 2017; Yang et al., 2019). Among structural characteristics, floor level, housing size, and the number of rooms are the essential attributes affecting dwelling prices (Tse \& Love, 2000). The dwelling unit with a more floor size or covered area has more space for living, which ultimately increases the utility of the residential property. The upper floor is generally linked with good air quality and view and, thus, higher property values. On the contrary, it is evidenced that the building age negatively affects the price of properties (Chen \& Jim, 2010). Urban amenities are also quite influential on the housing prices; the study conducted by Das et al. (2017) revealed that neighborhood amenities positively impact the price of residential housings even in the slum clusters. Residents showed more willingness to pay for the location with facilities like sewerage and street lights. Locational characteristics describe the environmental quality of the area where the properties are situated and the accessibility to several public facilities from the properties. Locational and environmental externalities could be either negative or positive, depending on the creation of cost or benefit to the neighborhood
(Muhammad, 2017). Plenty of research has been carried out to estimate the effects of location and environmental specific externality on residential prices. For instance, the externality effects of public parks on the neighborhood were studied by Park et al. (2017), and Jung et al. (2016). The parks and urban green places provide leisure opportunities to the vicinity and also improve the quality of life and the surrounding environment (Park et al., 2017). Enhancement in the neighborhood quality standards leads to a boost up the value of adjacent housing. The accessibility to transportation facilities is another essential locational attribute for the properties. Prior studies evidenced, convenient transportation facilities positively affect the value of surrounding houses (Bowes \& Ihlanfeldt, 2001; Karanikolas \& Louka, 2012; Trojanek \& Gluszak, 2018; Yang et al., 2019).

As discussed, consequently, the neighborhood quality significantly affects the value of properties. Mainly extensive improvements work such as redevelopment enhances the quality of the neighborhood leads enhancement in the values of adjacent properties. The urban redevelopment projects improve the quality of the vicinity environment by removing negative externalities, which also raises the value of adjacent residential properties. Past studies evidenced the role of urban redevelopment on the neighboring residential prices. The study conducted by Lee et al. (2017) investigated the urban renewal impact on the surrounding residential prices by using the difference-in-difference technique in Taipei, Taiwan. The empirical results revealed that the residential prices of closer proximity to renewal projects were increased after publically announcement of renewal projects. The increase in house prices nearby urban renewal sites indicates the positive effects of the redevelopment projects on the residential properties. Another study by Zheng et al. (2020) used the differencein-difference technique, found significant positive effects of urban redevelopment projects on the proximate housing prices in Hong Kong.

Liang et al. (2020) used spatial econometrics and different-in-difference methods to evaluate the urban renewal effects on the neighboring residential prices. They assessed and compared the effects of urban renewal on surrounding residential prices by dividing the process of urban renewal into two stages. The results revealed that the neighborhood housing prices of urban renewal projects were affected positively even before the accomplishment of reconstruction. Liu et al. (2015) examined the urban redevelopment effects on the housing prices in Shenzhen, China. The applied two different specifications of the hedonic price model, Spatial Lag Model, and Ordinary Least Squares. The empirical results showed that untreated renewal sites negatively influenced proximate housing prices and the expected or actual urban projects reduced the adverse influence.

$\mathrm{Ki}$ and Jayantha (2010) also investigated the impact of urban renewal projects on residential prices during pre and post redevelopment phases by using a price gradient 
approached based hedonic model to explore how urban renewal affects the residential prices in the vicinity. The empirical results revealed that the property prices were significantly enhanced pre-development and after the implementation of the renewal projects. Houses located closer to redeveloped sites have experienced higher prices after the completion of the projects but the prices were rising slowly during the construction stage, which indicated that the values of the property are associated with their neighborhood quality. Therefore, urban redevelopment's spillover effects should be taken into account while evaluating residential property values in the redevelopment area. Research work in this regard exists in the literature, for instance (Jayantha \& Chun Ming, 2015; Newell, 2010; Patel, 2013; Rosenthal \& Helsley, 1994). The redevelopment of urban decay sites helps to remove negative externalities and improve the quality of the surrounding environment. For instance, improvement in aged buildings and infrastructure, and removal of urban black spots can reduce the public health and risk hazards (Mukhija, 2002).
Moreover, the redevelopment of urban sites will generate positive neighborhood externalities. The urban areas development, the provision of green features, and open spaces in redevelopment sites enhance the value of the nearby property. In the literature of urban economics, the researchers conducted some studies regarding the redevelopment of urban areas and their effects on the surrounding residential properties. Table 1 shows a summary of some studies on urban development and their spillover effects on property value.

\section{Methodology}

\subsection{Model}

The value of nonmarketable goods is mostly assessed by employing two methods, the Revealed preference method known as the Hedonic price model (HPM) and the Stated preference method's Contingent valuation model (CVM) (Park et al., 2017). The contingent valuation method is

Table 1. Summary of previous hedonic studies on urban redevelopment and property value

\begin{tabular}{|c|c|c|c|c|c|}
\hline $\begin{array}{l}\text { Author } \\
\text { references }\end{array}$ & $\begin{array}{c}\text { Neighborhood } \\
\text { development }\end{array}$ & Model & Property type & Location & Results summary \\
\hline $\begin{array}{l}\text { Ki and Jayantha } \\
\text { (2010) }\end{array}$ & $\begin{array}{l}\text { Urban } \\
\text { redevelopment }\end{array}$ & HPM & $\begin{array}{l}\text { Residential } \\
\text { property }\end{array}$ & Hong Kong & $\begin{array}{l}\text { The results revealed that the prices of } \\
\text { properties were significantly increased after } \\
\text { the completion of the project as well after the } \\
\text { announcement before the implementation of } \\
\text { the project. The residential property prices } \\
\text { were increased regularly throughout different } \\
\text { stages of the project are also observed }\end{array}$ \\
\hline $\begin{array}{l}\text { Zahirovich- } \\
\text { Herbert and } \\
\text { Gibler (2014) }\end{array}$ & $\begin{array}{l}\text { New residential } \\
\text { construction }\end{array}$ & $\begin{array}{l}\text { HPM } \\
\text { Quantile } \\
\text { regression } \\
\text { model }\end{array}$ & $\begin{array}{l}\text { Residential } \\
\text { housing } \\
\text { property }\end{array}$ & USA & $\begin{array}{l}\text { The results showed large atypical new } \\
\text { dwellings command a premium. Furthermore, } \\
\text { the value of residential houses situated nearby } \\
\text { new residential construction sites enhance } \\
\text { because of development in the neighborhood }\end{array}$ \\
\hline $\begin{array}{l}\text { De Sousa et al. } \\
(2009)\end{array}$ & $\begin{array}{l}\text { Brownfield } \\
\text { redevelopment }\end{array}$ & HPM & $\begin{array}{l}\text { Residential } \\
\text { property }\end{array}$ & $\begin{array}{l}\text { Milwaukee and } \\
\text { Minneapolis, } \\
\text { USA }\end{array}$ & $\begin{array}{l}\text { The outcomes of the study revealed that } \\
\text { both quantity and geographic scope were } \\
\text { significantly enhanced the surrounding } \\
\text { property value. The net benefit of urban } \\
\text { brownfield redevelopment increased the } \\
\text { property value around } 2.7 \% \text { in Minneapolis } \\
\text { and } 11.4 \% \text { in Milwaukee }\end{array}$ \\
\hline $\begin{array}{l}\text { Jayantha and } \\
\text { Chun Ming } \\
\text { (2015) }\end{array}$ & $\begin{array}{l}\text { Urban } \\
\text { redevelopment }\end{array}$ & HPM & $\begin{array}{l}\text { Retail } \\
\text { shopping } \\
\text { property }\end{array}$ & Hong Kong & $\begin{array}{l}\text { The results indicated that the urban } \\
\text { redeveloped vicinity environment led to } \\
\text { a significant rise in the value of adjacent } \\
\text { commercial properties. The potential renter is } \\
\text { ready to pay premium rent prices for the shops } \\
\text { located nearby urban development sites. The } \\
\text { redevelopment enhances the value of shops } \\
\text { ranging from } 13 \% \text { to } 34 \% \text {. Furthermore, shops } \\
\text { with a cockloft enjoy a more rental premium } \\
\text { of } 0.1 \% \text { from potential tenants }\end{array}$ \\
\hline $\begin{array}{l}\text { Simons et al. } \\
\text { (1998) }\end{array}$ & $\begin{array}{l}\text { New residential } \\
\text { construction }\end{array}$ & $\begin{array}{l}\text { Two-stage } \\
\text { HPM }\end{array}$ & $\begin{array}{l}\text { Residential } \\
\text { houses }\end{array}$ & USA & $\begin{array}{l}\text { The results showed significant positive effects of } \\
\text { new housing construction on nearby housing } \\
\text { prices. Each additional unit of a new house } \\
\text { built in a block section significantly enhances } \\
\text { the price of } \$ 670 \text {. Furthermore, the reduction in } \\
\text { the sale price is connected with the increase in } \\
\text { tax delinquency rate increased by } 1 \%\end{array}$ \\
\hline
\end{tabular}


mainly employed the stated preference method, a nonmarket valuation technique, and a method of direct survey used to evaluate the economic value of the commodities by examining individuals for their willingness to pay. The HPM is the indirect approach extensively employed to assess the worth of goods and services, or an environmental asset usually relies on individual preferences (Hussain et al., 2021). At the same time, the transaction and precisely explores the situation of the market. The benefits of ecological amenity and disamenity (such as proximity to the recreation site, proximity to landfill) assessed by estimating the sale value of the property, so the influence in property value portion by amenity and disamenity attributes could be computed statically (Jim \& Chen, 2006).

Currently, the hedonic pricing model is a method being employed to examine a wide range of externalities. Among different externalities, this method is mostly used in the valuation of locational and environmental disamenities and amenities throughout the world, such as environmental and issues caused by dangerous industrial sites (Grislain-Letrémy \& Katossky, 2014), environmental contamination (Kiel, 2017), and nuclear power plants (Bauer et al., 2017). This method is also employed to examine the adverse effects of undesirable land use on property value, such as Sanitary landfill (Akinjare et al., 2011), neighborhood crime (Pope \& Pope, 2012), and waste dump sites (Bello \& Bello, 2009). This application of HPM has also been used to investigate the effects of positive externalities on the property value such as parks (Park et al., 2017), public green places (McCord et al., 2014), development of new grocery stores (Cerrato Caceres \& Geoghegan, 2017), urban redevelopment project (Jayantha \& Chun Ming, 2015). However, the HPM method is most reliable and acceptable in the assessment of externalities and property markets.

The HPM compromises of several functional forms to assess the value of goods. Researchers have the option to choose a suitable functional form according to the nature of particular empirical work. Therefore, three functional forms of the model are frequently used by researchers such as linear functional form (Palmquist, 1984), loglinear functional form (Kaufman \& Cloutier, 2006), and log-log functional form (Basu \& Thibodeau, 1998).

This study incorporated both the linear and semi-log functional form of the HPM to measure the association between the house value and several features of the housing unit.

The functional form of the linear model

$R p=b 0+b 1 H_{\text {age }}+b 2 H_{\text {size }}+b 3$ Bedroom $+b 4$ Drawing + $b 5$ Bathroom $+b 6 T V_{\text {Lounge }}+b 7$ Garage $+b 8$ Srvt $_{\mathrm{Qtr}}+$

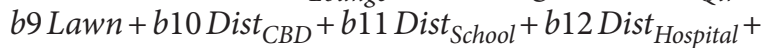
$b 13$ Dist $_{\text {Markaz }}+b 14$ Dist $_{\text {Park }}+b 15$ Dist $_{\text {Slum }}+b 16$ Visibility $+\varepsilon \ldots \ldots \ldots$.

The functional form of Semi-log or Log-linear Model

LnRp $=b 0+\mathrm{b} 1 H_{\text {age }}+b 2 H_{\text {size }}+b 3$ Bedroom $+b 4$ Draw $i n g+b 5$ Bathroom $+b 6 T V_{\text {Lounge }}+b 7 G a-$ rage $+b 8 S r v t_{Q t r}+b 9 L a w n+b 10$ Dist $_{C B D}+b 11$ Dist $_{S_{\text {chool }}}+$

$$
\begin{aligned}
& b 12 \text { Dist }_{\text {Hospital }}+b 13 \text { Dist }_{\text {Markaz }}+b 14 \text { Dist }_{\text {Park }}+b 15 \text { Dist }_{\text {Slum }}+ \\
& b 16 \text { Visibility }+\varepsilon \ldots \ldots \ldots . .
\end{aligned}
$$

where: $\operatorname{LnRp}$ - is a dependent variable that represents the $\log$ of the rental value of the housing unit; $b 1$ to $b 16$ - represents structural, locational, and environmental variables of the model; $\varepsilon$ - represents the error term.

\subsection{Study variables}

Mainly three categories of variables are applied to investigate the influence of neighborhood externalities on the surrounding property values, such as physical features of the housing unit, locational attributes, and environmental attributes (Rosen, 1974). The variables for this study are based on the conceptual model presented in Figure 1.

The physical features of a dwelling unit include building size, age, number of bedrooms, and floor height are considered the essential features that affect dwelling value. The study consists of the structural variable commonly used by the past researchers such as a square yard of house size $\left(H_{\text {size }}\right)$, age of the housing unit $\left(H_{\text {age }}\right)$, no of bedrooms (BEDROOMS) and bathrooms (BATHROOMS) in the house, availability of drawing-room (DRAWING), the particular space in the house for the visitors or guests only. The availability of a garage/parking space (GARAGE), presence of lawn (LAWN), and TV Lounge ( $\left.T V_{\text {Lounge }}\right)$.

The location is one of the influential elements that influence the value of residential properties. The central business district (DIST_CBD) or city center is believed as a crucial variable of location (Bello \& Bello, 2009). It shows

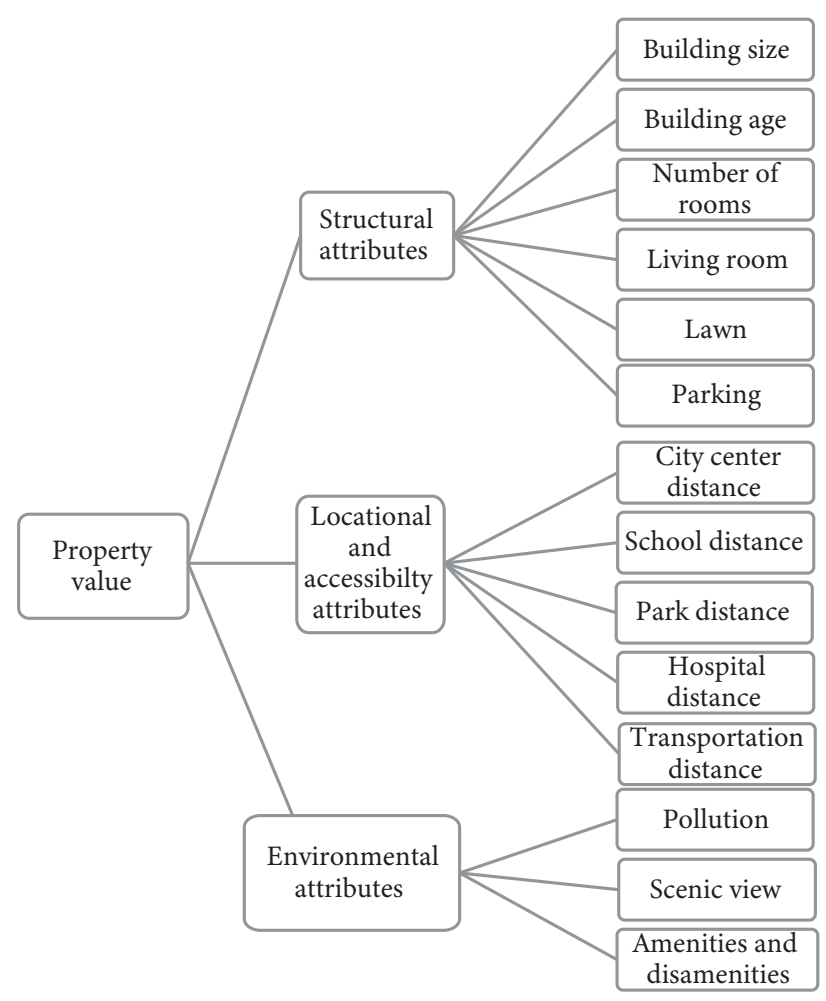

Figure 1. Conceptual framework 
the distance to the center of the city from the housing unit. Generally, the value of properties declines with the increasing distance between the housing unit and the city center. The distance to the public park is also one of the crucial variables used in past studies the measure the amenity of house value (Shukur et al., 2012). Neighborhood environmental externalities are also considered to be the influential factors of residential property values. The distance to up-graded slum settlements (DIST_UPGRD), evicted slum sites (DIST_EVT), and visibility (VISIBILITY) is a crucial variable of interest in the current research to evaluate the net beneficial impact of up-gradation and eviction of slum areas on the surrounding residential property value. Table 2 below shows selected variables for this study with expected positive or negative effects signs, whereas Table 3 stipulates the descriptive statistics related to dependent and explanatory variables.

\section{Materials and methods}

\subsection{Study area}

Islamabad is the tenth-largest city in Pakistan with a population of more than one million. The area covered by the city is $906.50 \mathrm{~km}^{2}$, which consists of both urban and rural parts. The rural areas comprise of $466 \mathrm{~km}^{2}$, the urban parts of the city comprise $220 \mathrm{~km}^{2}$, and open green places like parks covered an area of $220 \mathrm{~km}^{2}$. According to the urban development plan, Islamabad is divided into five main zones. Zone 2 is designated for residential purposes and it has a further nine sectors, and each sector is further divided into four sub-sector (Riddell, 2016).

\subsection{Data collection}

This study considered slum up-gradation and eviction projects from different sectors and sub-sectors of the residential zone in Islamabad. The study has randomly selected two unauthorized existing slum settlements, two slum up-gradation sites, and also two evicted/demolished slum sites from the target population of the same zone. To measure the influence of slum up-gradation and evictions projects on surrounding property value, first, we pre-defined the influence area by using the Google map. Then we marked three distance rings for each project, and thus each distance ring has a 250-meter distance. House units located within 250 meters from selected projects were included in ring 1, and house units' located in 250 to 500 -meter distance from slums were included in ring 2. House units situated more than a 500-meter distance from slum areas were considered in ring 3.

The study selects 30 housing units from each ring through random sampling. To ensure homogeneity among the study sample, we select single-family dwellings units. The selection of sampling was started from the northwest of each slum site, after choosing the first sample the next sample was selected by skipping the next four consecutive housing units in the same street. The same practice was sequenced until the required data received. The obtained data were screened, and incomplete responses were omitted, the study received 163 valid observations from existing slum sites, 173 from up-graded slum sites, and 168 observations from evicted slum sites to run the analysis. The study considers the rental value of the ground floor whether the

Table 2. Variables description

\begin{tabular}{|c|c|l|c|}
\hline Variable sign & Variable & \multicolumn{1}{|c|}{ Description of variables/explanation } & Expected effect \\
\hline H_age & House age & The house age in years & - \\
\hline H_size & House size & The area covered by housing unit (Sq./Yd) & + \\
\hline Bedrooms & Bedrooms & Bedrooms in the home & + \\
\hline Drawing & Drawing room & The dummy variable, shows a drawing-room, 1 or 0 & + \\
\hline Bathrooms & Bathrooms & Bathrooms in the home & + \\
\hline TV_Lounge & TV lounge & The dummy variable displays living area in the home, 1 or 0 & + \\
\hline Garage & Garage/parking & The dummy variable showing garage, 1 or 0 & + \\
\hline Srvt_Qtr & Servant quarter & The dummy variable shows servant quarter in home, 1 or 0 & + \\
\hline Lawn & Lawn & The dummy variable presenting a lawn in home, 1 or 0 & + \\
\hline Dist_CBD & Central business district & Distance from home to the city center & - \\
\hline Dist_School & School distance & Distance from home to school & - \\
\hline Dist_Park & Park distance & Distance from housing unit to park & - \\
\hline Dist_Slums & Slums distance & Distance from house to the sites where slums are still existing & + \\
\hline Dist_Upgrd & Upgraded slums distance & $\begin{array}{l}\text { Distance from house to such slums sites which are upgraded } \\
\text { and improved by government }\end{array}$ & + \\
\hline Dist_Evt & Evicted slums distance & $\begin{array}{l}\text { Distance from house to such slums sites which are evicted and } \\
\text { demolished by the government }\end{array}$ & + \\
\hline Visibility & Visibility & Visibility of upgraded, evicted slums from the house, 1 or 0 & + \\
\hline
\end{tabular}


house has more than one floor. We did not include the rental value of the other floors because commonly, lawn and parking facilities can exist on the ground floor. In order to assess the distance among the housing unit to various other locational variables, the GPS coordinates of each sampled housing unit were taken by using smartphone android application "Google Map". The distance of each location variable was calculated by using GPS coordinates in ArcGIS map software, the location of each sampled house in the geographical map can be seen in (Figure 2).

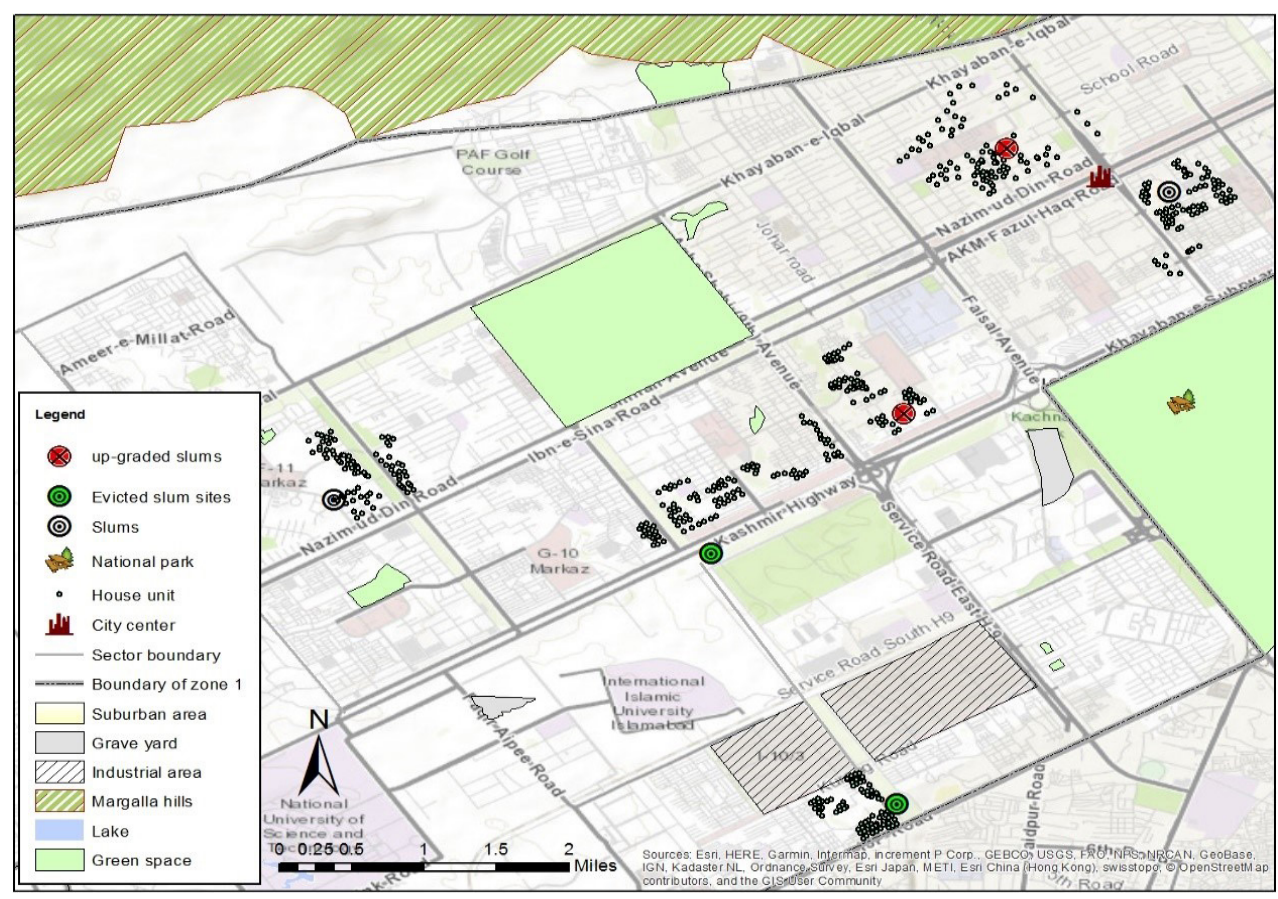

Figure 2. Selected sample houses in the study area

Table 3. Descriptive statistics

\begin{tabular}{|c|c|c|c|c|c|c|c|c|c|c|c|c|}
\hline \multirow{2}{*}{ Variables } & \multicolumn{4}{|c|}{ Existing slums areas } & \multicolumn{4}{|c|}{ Up-graded slums } & \multicolumn{4}{|c|}{ Evicted slum sites } \\
\hline & Min & Max & Mean & SD & Min & Max & Mean & SD & Min & Max & Mean & $\mathrm{SD}$ \\
\hline House rent (PKR) & 16020 & 86790 & 40987 & 13089.753 & 21100 & 99251 & 54279.91 & 19092.55 & 25000 & 57300 & 37904.56 & 7589.429 \\
\hline Log of rent & 9.68 & 11.37 & 10.572 & 0.316 & 9.96 & 11.51 & 10.839 & 0.362 & 10.13 & 10.96 & 10.523 & 0.197 \\
\hline House age & 2 & 35 & 15.43 & 8.376 & 1 & 44 & 15.64 & 9.142 & 1 & 31 & 13.11 & 6.281 \\
\hline House unit size & 75 & 714 & 264.18 & 141.514 & 75 & 816 & 317.32 & 182.569 & 151 & 453 & 209.09 & 60.52 \\
\hline Bedrooms & 1 & 4 & 2.15 & 0.764 & 1 & 5 & 2.51 & 0.95 & 1 & 4 & 1.79 & 0.708 \\
\hline Drawing room & 0 & 1 & 0.9 & & 0 & 1 & 0.91 & & 0 & 1 & 0.79 & \\
\hline Bathrooms & 1 & 3 & 1.63 & 0.608 & 1 & 5 & 2.03 & 0.879 & 1 & 3 & 1.38 & 0.498 \\
\hline TV lounge & 0 & 1 & 0.91 & & 0 & 1 & 0.82 & & 0 & 1 & 0.74 & \\
\hline Garage & 0 & 1 & 0.83 & & 0 & 1 & 0.84 & & 0 & 1 & 0.77 & \\
\hline Servant quarter & 0 & 1 & 0.27 & & 0 & 1 & 0.46 & & 0 & 1 & 0.43 & \\
\hline Lawn & 0 & 1 & 0.79 & & 0 & 1 & 0.83 & & 0 & 1 & 0.71 & \\
\hline Distance to CBD & 0.42 & 8.11 & 4.289 & 3.423 & 0.46 & 4.3 & 2.353 & 1.239 & 3.64 & 8.44 & 6.745 & 1.404 \\
\hline Distance to school & 0.02 & 0.84 & 0.4 & 0.184 & 0.5 & 2.63 & 1.471 & 0.544 & 0.06 & 1.69 & 0.661 & 0.465 \\
\hline Distance to park & 0.11 & 1.61 & 0.643 & 0.312 & 1.99 & 4.95 & 3.208 & 0.807 & 0.09 & 1.36 & 0.534 & 0.251 \\
\hline $\begin{array}{l}\text { Distance to existing } \\
\text { slums }\end{array}$ & 0.08 & 1 & 0.483 & 0.207 & & & & & & & & \\
\hline $\begin{array}{l}\text { Distance to up- } \\
\text { graded slums }\end{array}$ & & & & & 0.11 & 1 & 0.541 & 0.252 & & & & \\
\hline $\begin{array}{l}\text { Distance to evicted } \\
\text { slums }\end{array}$ & & & & & & & & & 0.09 & 1 & 0.584 & 0.245 \\
\hline Visibility & 0 & 1 & 0.07 & & 0 & 1 & 0.11 & & 0 & 1 & 0.05 & \\
\hline
\end{tabular}




\section{Results and discussion}

Tables 4, 5, and 6 show the estimations of the regressions function of existing slum areas, up-gradated slums, and the evicted slum sites, respectively. These tables have results of both linear and log-linear or semi-log functional forms of the model. For the estimation of the effects of existing slums, upgraded slums, and evicted slum sites on house rental value, the study used three indicators: distance to existing slums, distance to upgraded slums, and distance to evicted slum sites. Thus, each table has two models, and each table is with different indicators, whereas each model is assessed with both semi-log and linear specifications.

\subsection{Effects of existing slums on the rental price}

The values of the adjusted $\mathrm{R}^{2}$ are from 0.9416 to 0.9504 in the log-linear and linear model that shows the model's independent variables can explain around 94 to 95 percent fluctuation of the dependent variable and be able to indicate the models goodness of fit.

The results of the linear model demonstrate that the house located a distance of one kilometer away from existing slums enjoys more rental value of PKR 5894. It means the housing units with the same attributes located one kilometer closer to slum areas lost their rental value around PKR 5894 for existing near to slum areas. On the other hand, the log-liner model results also reveal rent price discount for the dwellings situated within a kilometer distance from the slum sites, housing units lost almost 18.6\% rental value for being located nearby slum areas as compared to those similar houses located a kilometer away from such slum sites (see Table 4). Furthermore, dwelling units located very close to slum sites are affected the most, the visibility of the nearest slums from the house also decreases the rental value by around $15 \%$.

\subsection{Effects of slum up-gradation on the rental price}

Table 5 presents the regression results estimation of both linear and log-linear models. General, the signs of the coefficients seem as expected, however statistically few variables are not significant. The $\mathrm{R}^{2}$ (demonstrates the sum of the fluctuation in the dependent variable due to independent variables) is $93 \%$ in the linear model and $91 \%$ in the Semi-log or log-linear model, which is highly satisfactory.

The results show the gap between residential housing units and up-graded slum areas are positively correlated with each other, as distance increases from the up-graded slum sites, the rental prices also increase. Meanwhile, the rental prices decrease as distance decreases from the upgraded slums. The distance to the up-graded slum site, we observe that its parameter estimate is positive and highly significant statistically at the 99 percent level in both models. The coefficient estimated with the semi-log functional form shows that the housing unit located $1 \mathrm{~km}$ away from the up-graded slums, rental prices of residential housing units increase by between $12.5 \%$ (see Table 5). That means houses located one kilometer closer to up-graded slums lose the rental value of $12.5 \%$ as compare to those housing

Table 4. Presenting estimates of a linear and log-linear model with data from existing slums

\begin{tabular}{|c|c|c|c|c|c|c|}
\hline \multirow{2}{*}{ Variables } & \multicolumn{3}{|c|}{ Linear model } & \multicolumn{3}{|c|}{ Log-linear model } \\
\hline & Coefficients & Std. Err. & $t$-value & Coefficients & Std. Err. & $t$-value \\
\hline House age & $66.18976^{*}$ & 33.64222 & 1.97 & $.0018017^{\star}$ & .0008823 & 2.04 \\
\hline House unit size & $79.99556^{* *}$ & 4.551541 & 17.58 & $.0013917^{\star *}$ & .0001194 & 11.66 \\
\hline Bedrooms & $1690.173^{\star \star}$ & 554.19 & 3.05 & $.0420453^{* \star}$ & .0145349 & 2.89 \\
\hline Drawing room & $2549.089^{* \star}$ & 852.2414 & 2.99 & $.0834143^{* \star}$ & .0223519 & 3.73 \\
\hline Bathrooms & 734.8915 & 620.7361 & 1.18 & .0181466 & .0162802 & 1.11 \\
\hline TV lounge & $2003.42^{\star}$ & 953.2602 & 2.10 & $.087841^{\star *}$ & .0250014 & 3.51 \\
\hline Garage & 977.9888 & 707.9799 & 1.38 & $.0537868^{\star \star}$ & .0185684 & 2.90 \\
\hline Servant quarter & $2646.275^{\star \star}$ & 671.7168 & 3.94 & $.0585302^{\star \star}$ & .0176173 & 3.32 \\
\hline Lawn & $1815.562^{\star \star}$ & 679.3289 & 2.67 & $.0913645^{\star \star}$ & .0178169 & 5.13 \\
\hline Distance to CBD & $1113.781^{\star *}$ & 142.3801 & 7.82 & $.0122385^{\star \star}$ & .0037342 & 3.28 \\
\hline Distance to school & 1324.727 & 1594.824 & 0.83 & .0751735 & .0418278 & 1.80 \\
\hline Distance to park & $3562.901^{\star \star}$ & 999.7477 & 3.56 & $.1086817^{\star \star}$ & .0262206 & 4.14 \\
\hline Distance to slums & $5894.832^{\star \star}$ & 1632.232 & 3.61 & $.1864864^{* \star}$ & .0428089 & 4.36 \\
\hline Visibility & $5985.225^{\star \star}$ & 1228.731 & 4.87 & $.151787^{\star \star}$ & .0322262 & 4.71 \\
\hline _cons & $14133.57^{\star \star}$ & 2084.127 & 6.78 & $9.837591^{\star *}$ & .0546609 & 179.97 \\
\hline R-squared & 0.9547 & & & 0.9466 & & \\
\hline Adj R-squared & 0.9504 & & & 0.9416 & & \\
\hline Prob $>$ F & 0.0000 & & & 0.0000 & & \\
\hline
\end{tabular}

Note: ${ }^{\star},{ }^{*}$ denotes significance at $5 \%$ and $1 \%$ levels. 
Table 5. Showing estimates of a linear and semi-log model with data from upgraded slums

\begin{tabular}{|c|c|c|c|c|c|c|}
\hline \multirow{2}{*}{ Variables } & \multicolumn{3}{|c|}{ Linear model } & \multicolumn{3}{|c|}{ Log-linear model } \\
\hline & Coefficients & Std. Err. & $t$-value & Coefficients & Std. Err. & $t$-value \\
\hline House age & $166.016^{\star *}$ & 45.90104 & 3.62 & $.0045487^{\star *}$ & .0010464 & -4.35 \\
\hline House unit size & $65.67229^{\star *}$ & 4.548889 & 14.44 & $.0009076^{\star *}$ & .0001037 & 8.75 \\
\hline Bedrooms & $2041.083^{\star *}$ & 718.7292 & 2.84 & $.0488116^{\star *}$ & .0163849 & 2.98 \\
\hline Drawing room & $3378.79^{\star}$ & 1378.357 & 2.45 & $.067677^{\star}$ & .0314224 & 2.15 \\
\hline Bathrooms & 894.3884 & 678.3305 & 1.32 & .0122106 & .0154639 & 0.79 \\
\hline TV lounge & 1652.742 & 1157.746 & 1.43 & $.0591468^{*}$ & .0263932 & 2.24 \\
\hline Garage & 1545.144 & 1140.948 & 1.35 & $.0643446^{*}$ & .0260102 & 2.47 \\
\hline Servant quarter & $3936.82^{* *}$ & 1136.299 & 3.46 & $.088549^{* *}$ & .0259043 & 3.42 \\
\hline Lawn & $2333.943^{\star}$ & 1089.434 & 2.14 & $.0558746^{*}$ & .0248359 & 2.25 \\
\hline Distance to CBD & $4085.165^{\star *}$ & 808.8975 & 5.05 & $.1300239^{\star *}$ & .0184405 & -7.05 \\
\hline Distance to school & $2238.825^{*}$ & 1076.843 & 2.08 & $.0511055^{\star}$ & .0245488 & -2.08 \\
\hline Distance to park & $2816.003^{*}$ & 1211.215 & 2.32 & $.086923^{* *}$ & .0276121 & -3.15 \\
\hline Distance to upgraded slums & $6568.099^{* *}$ & 2070.675 & 3.17 & $.1258162^{\star *}$ & .0472052 & 2.67 \\
\hline Visibility & $4921.391^{\star *}$ & 1451.89 & 3.39 & $-.1080642^{\star *}$ & .0330988 & -3.26 \\
\hline _cons & $38553.44^{\star *}$ & 6267.595 & 6.15 & $10.82699^{\star *}$ & .1428826 & 75.78 \\
\hline R-squared & 0.9441 & & & 0.9193 & & \\
\hline Adj R-squared & 0.9392 & & & 0.9121 & & \\
\hline Prob $>$ F & 0.0000 & & & 0.0000 & & \\
\hline
\end{tabular}

Note: ${ }^{*},{ }^{*}$ denotes significance at $5 \%$ and $1 \%$ levels.

units situated a kilometer away from up-graded slum areas. Furthermore, the linear model shows PKR 4921, and the log-linear model reveals a $10.8 \%$ less rental price for housing units close enough to visible to up-graded slums.

\subsection{Effects of slum eviction/demolition on the rental price}

Table 6 represents the estimation results of the eviction of slum areas' effects on house rental value by using linear and log-linear models. The satisfactory level of adjusted $\mathrm{R}^{2}$ of both models demonstrates the model's goodness of fit. The distance to the evicted slum sites (the critical variable in this model) is associated with an increase in rental price at a rate of $6.7 \%$ per kilometer, keeping other variables in the model constant. That means houses situated a kilometer closer to evicted slum sites have a discount on the rental price of $6.7 \%$.

The findings of the current study reveal the significant positive effect of both the up-gradation and eviction of slum areas on the residential housing rental value. It suggests that slum up-gradation and eviction of unauthorized katchi abadis has brought improvements to the neighboring environment, and the public anticipation regarding the advantages of improved environment and amenities trigger the appreciation of the residential prices. The findings of the current study are somehow comparable with the findings of some urban development studies such as De Sousa et al. (2009) and Ki and Jayantha (2010) even though Zhang et al. (2016) study are about evictions of inferior settlements (urban villages) on residential prices. However, the comparability needs to be done much carefully as the redevelopment of slums is unmatchable with the previous research. The evidence of a study conducted by Zhang et al. (2016) found the net benefits of the eviction of the urban villages on residential property prices in Beijing, China. The study showed that an average urban village negatively affects residential prices of around $2.5 \%$ of nearby housing societies, and the removal or demolition of an urban village enhances the value of neighboring housing up to $3.4 \%$. The study showed lower adverse effects of urban villages on the residential properties as compared to slums or katchi abadis. The reason for this is might be because of the difference in characteristics of urban villages and katchi abadis. The urban villages in China are different from the slums in Pakistan. Urban villages are formal settlements with tenure security, and the government is responsible for the development.

In contrast, slums or katchi abadis are informal settlements and do not have land ownership rights, and the government is not responsible for the development. The situation in katchi abadis is more deteriorated and causes several socio-economic, political, and environmental issues as compared to the urban villages. The evidence of the study conducted by De Sousa et al. (2009) on the impact of the redevelopment of Brownfields on the residential value in Milwaukee and Minneapolis, United States, revealed the net benefit of urban brownfield redevelopment increased the residential property value by around 
Table 6. Showing estimates of a linear and semi-log model with data from evicted slum sites

\begin{tabular}{|c|c|c|c|c|c|c|}
\hline \multirow{2}{*}{ Variables } & \multicolumn{3}{|c|}{ Linear model } & \multicolumn{3}{|c|}{ Log-linear model } \\
\hline & Coefficients & Std. Err. & $t$-value & Coefficients & Std. Err. & $t$-value \\
\hline House age & 71.68437 & 38.28094 & 1.87 & .0013215 & .0010493 & -1.26 \\
\hline House unit size & $77.49149^{* *}$ & 5.64242 & 13.73 & $.001857^{\star \star}$ & .0001547 & 12.01 \\
\hline Bedrooms & $1596.682^{* *}$ & 413.7285 & 3.86 & $.0443812^{\star *}$ & .0113403 & 3.91 \\
\hline Drawing room & 950.7497 & 585.3236 & 1.62 & $.033505^{\star}$ & .0160437 & 2.09 \\
\hline Bathrooms & $951.5119^{*}$ & 460.7668 & 2.07 & .0222714 & .0126296 & 1.76 \\
\hline TV lounge & $1137.778^{*}$ & 511.8009 & 2.22 & $.0327429^{*}$ & .0140285 & 2.33 \\
\hline Garage & $1375.326^{\star}$ & 527.7794 & 2.61 & $.0337009^{*}$ & .0144664 & 2.33 \\
\hline Servant quarter & $2524.987^{\star \star}$ & 631.1266 & 4.00 & $.0794629^{\star *}$ & .0172992 & 4.59 \\
\hline Lawn & $1034.311^{\star}$ & 502.4433 & 2.06 & $.0295001^{*}$ & .013772 & 2.14 \\
\hline Distance to CBD & $809.7306^{*}$ & 330.3623 & 2.45 & $.0184054^{\star}$ & .0090552 & -2.03 \\
\hline Distance to school & $1809.456^{\star *}$ & 688.3523 & 2.63 & -.0361071 & .0188677 & -1.91 \\
\hline Distance to park & $2949.794^{* *}$ & 1098.344 & -2.69 & $-.0778371^{*}$ & .0301056 & -2.59 \\
\hline Distance to evicted slums & $2930.03^{*}$ & 1490.882 & 1.97 & $.0792828^{\star}$ & .0408651 & 1.94 \\
\hline Visibility & $2237.263^{\star}$ & 1077.658 & -2.08 & $-.0676483^{\star}$ & .0295386 & -2.29 \\
\hline _cons & $20617.66^{* *}$ & 3801.181 & 5.42 & $10.05659^{* *}$ & .1041903 & 96.52 \\
\hline R-squared & 0.8817 & & & 0.8683 & & \\
\hline Adj R-squared & 0.8709 & & & 0.8563 & & \\
\hline Prob $>$ F & 0.0000 & & & 0.0000 & & \\
\hline
\end{tabular}

Note: ${ }^{*}{ }^{* *}$ denotes significance at $5 \%$ and $1 \%$ levels.

2.7\% in Minneapolis and $11.4 \%$ in Milwaukee. The net benefit of the redevelopment of brownfields in the Milwaukee region is nearly matching with the net benefit of the eviction of katchi abadis of the current study.

The functions of regression in Tables 4, 5, and 6 display the figures, as well as the estimated sign of neighborhood and structural characteristics in existing slum sites, up-gradated slums, and the evicted slum site data, are as expected in all model specifications of both linear and log-linear models. The log-linear model showed more significant results as compared to the linear model. The study more precisely included the results of the log-linear specification to explain the structural and accessibility variables of the study. The variables for physical attributes of dwellings have the anticipated coefficient signs and are mostly coherent with the outcomes of immense literature of hedonic modeling. For instance, the additional bedroom surges the rental value of the house by $4.2 \%$ in the existing slum site.

Nevertheless, the enhancement in rental price due to the existence of an additional bedroom is $4.4 \%$ in the case of evicted slum site areas. The presence of a servant quarter in the house increases the rental value by up to $5.8 \%$ in the existing slum areas and $8.8 \%$ in the up-graded slum areas. It is $7.9 \%$ in the evicted slum site. The size of the dwelling unit is the most influential independent variable to forecast the rental price, with the highest $t$-value of 11.66, 8.75 , and 12.01, respectively, among all other independent variables. Against anticipations, the additional bathroom does not significantly affect the rental price in all data sets of the log-linear model. Furthermore, the presence of garage or parking space was given equal importance by both models, with an approximate $t$-value of 2.90 in the existing slum sites, 2.47 in the up-graded slum sites, and 2.33 in the evicted slums sites data set. The results also show that the presence of lawn enhances the rental price by approximately $9 \%$ in existing slum sites, $5 \%$ in up-graded slum areas, and $2 \%$ in evicted slum sites data set (see Tables 4 , $5,6)$. The presence of public facilities enhances the rental value of nearby houses, distance increases between public services and housing units significantly reduces the rental value of residential property in the market.

\section{Conclusions and policy implications}

The study aimed to examine the value enhancement impact of urban slums improvement and redevelopment policies on the rental prices of residential property. This study used slum up-gradation and eviction projects to evaluate this issue empirically. The results of the study depict that redevelopment resulted in substantial value enhancement to neighboring residential property. Notably, the rental prices of residential units in the vicinity of evicted and upgraded slum sites have been increased significantly. The results suggest that potential house residents seem more willing to spend for a house that is situated nearer to the redeveloped locality. 
From these findings, we can draw various conclusions. Firstly, for landlords and developers, an enhanced environment neighborhood quality can undoubtedly be seen as a vital selling point. Those slum development projects which are well planned and implemented are capable of enhancing the environment of the vicinity and support the marketability and value of surrounding properties. Hence, an enhanced environment of the vicinity is like a guarantee or promise from the authorities of urban development. Therefore, the residential property values will reach to highest standards. Finally, it helps to surge the competitiveness and marketability of the properties.

Consequently, the authorities of urban development and planning possibly will consider the actual benefits that slum redevelopment creates in the market in particular and the society in a broad-spectrum. Secondly, the awareness of people about the real benefits of the slum redevelopment will be enhanced. The positive perception of the general public creates a favorable impression of the slum's redevelopment in the society at large. Consequently, the negative attitudes in particular segments of society about slum redevelopment will be changed.

The findings of the current study indicate specific necessary implications. Considering policymaking bodies, this study highlights the main underlying assumptions about the implementation of the slums redevelopment process: the advantages received by the nearby real estate market because of improvement in proximate slum settlements. It is due to the slum redevelopment capability for enhancing the environment of urban living, hence increases the life quality, city image, and safety of the public. Additionally, it also helps to improve the property values in the vicinity that will result in an increase of tax base for relevant authorities. Though slum redevelopment projects incur high costs, developers and authorities think that the measures taken for raising public awareness about the slum redevelopment will be a business opportunity for them. It could also assist in enhancing redevelopment policies and implications and increasing redevelopment demand in the market.

Moreover, the findings could also help bring the attitude of Islamabad to improve the environment at a higher standard. Due to a lack of awareness of the potential benefits of slum redevelopment, several segments of society are reluctant to support the slum area's redevelopment. So these findings will also be helpful for those sections and authorities to understand the real benefits of slum redevelopment. This will help authorities to make decisions when to go for redeveloping a slum area as it should be taken place when the worth of property/land of a new expansion surpasses the worth of properties outstanding in its present use. The present study has some limitations which need to be acknowledged. The lack of housing sales transaction data is one of the limitations of the study. The function of hedonic price modeling is based on the selfreported rental price of housing units, related research is usually done with the sale price of the residential unit.
The study is limited to the influences of slum improvement or redevelopment policies on the residential prices only; the studies in the future may include the value of properties in the commercial and industrial areas. Hence, further research requires more precise data for testing and consolidating the findings of this study.

\section{Acknowledgements}

Authors are thankful to College of Public Administration, Nanjing Agricultural University (NJAU).

\section{Funding}

The APC was funded by Nanjing Agricultural University, China.

\section{Author contributions}

T. H. has conceptualized, drafted methodology, data collected and analyzed, while Z. W. supervised and reviewed the edited manuscript.

\section{Disclosure statement}

The authors have no competing interests.

\section{References}

Akinjare, O. A., Ayedun, C. A., Oluwatobi, A. O., \& Iroham, O. C. (2011). Impact of sanitary landfills on urban residential property value in Lagos State, Nigeria. Journal of Sustainable Development, 4(2), 48-60. https://doi.org/10.5539/jsd.v4n2p48

Asian Development Bank and Inter-American Development Bank. (2014). Sustainable urbanization in Asia and Latin America. Asian Development Bank.

Basu, S., \& Thibodeau, T. G. (1998). Analysis of spatial autocorrelation in house prices. The Journal of Real Estate Finance and Economics, 17(1), 61-85.

https://doi.org/10.1023/A:1007703229507

Bauer, T. K., Braun, S. T., \& Kvasnicka, M. (2017). Nuclear power plant closures and local housing values: evidence from Fukushima and the German housing market. Journal of Urban Economics, 99, 94-106. https://doi.org/10.1016/j.jue.2017.02.002

Bello, V. A., \& Bello, M. O. (2009). Valuation of properties in close proximity to waste dumps sites: the Nigeria experience. International Journal of Strategic Property Management, 13(4), 309-317. https://doi.org/10.3846/1648-715X.2009.13.309-317

Bowes, D. R., \& Ihlanfeldt, K. R. (2001). Identifying the impacts of rail transit stations on residential property values. Journal of Urban Economics, 50(1), 1-25.

https://doi.org/10.1006/juec.2001.2214

Cerrato Caceres, B., \& Geoghegan, J. (2017). Effects of new grocery store development on inner-city neighborhood residential prices. Agricultural and Resource Economics Review, 46(1), 87-102. https://doi.org/10.1017/age.2016.29

Chen, W. Y., \& Jim, C. Y. (2010). Amenities and disamenities: a hedonic analysis of the heterogeneous urban landscape in Shenzhen (China). The Geographical Journal, 176(3), 227240. https://doi.org/10.1111/j.1475-4959.2010.00358.x 
Das, S., Mitra, A., \& Kumar, R. (2017). Do neighbourhood facilities matter for slum housing? Evidence from Indian slum clusters. Urban Studies, 54(8), 1887-1904.

https://doi.org/10.1177/0042098016634578

De Sousa, C. A., Wu, C., \& Westphal, L. M. (2009). Assessing the effect of publicly assisted brownfield redevelopment on surrounding property values. Economic Development Quarterly, 23(2), 95-110. https://doi.org/10.1177/0891242408328379

Grislain-Letrémy, C., \& Katossky, A. (2014). The impact of hazardous industrial facilities on housing prices: a comparison of parametric and semiparametric hedonic price models. Regional Science and Urban Economics, 49, 93-107. https://doi.org/10.1016/j.regsciurbeco.2014.09.002

Hussain, T., Abbas, J., Wei, Z., Ahmad, S., Xuehao, B., \& Gaoli, Z. (2021). The urban villages disamenity impact on neighboring residential property: an empirical evidence from Nanjing through hedonic pricing model appraisal. Journal of Urban Planning and Development, 147(1), 04020055. https://doi.org/10.1061/(ASCE)UP.1943-5444.0000645

Hussain, T., Abbas, J., Wei, Z., \& Nurunnabi, M. (2019). The effect of sustainable urban planning and slum disamenity on the value of neighboring residential property: application of the hedonic pricing model in rent price appraisal. Sustainability, 11(4), 1144. https://doi.org/10.3390/su11041144

Jayantha, W. M., \& Chun Ming, C. (2015). The effect of urban redevelopment on retail shopping property values: a case study in Hong Kong. International Journal of Urban Sciences, 19(3), 379-399. https://doi.org/10.1080/12265934.2015.1095111

Jim, C. Y., \& Chen, W. Y. (2006). Impacts of urban environmental elements on residential housing prices in Guangzhou (China). Landscape and Urban Planning, 78(4), 422-434. https://doi.org/10.1016/j.landurbplan.2005.12.003

Jung, E., Choi, Y., \& Yoon, H. (2016). The impact of the Gyeongui Line Park project on residential property values in Seoul, Korea. Habitat International, 58, 108-117. https://doi.org/10.1016/j.habitatint.2016.10.002

Karanikolas, N., \& Louka, E. (2012). The effect of metro station on commercial values of residential properties. The case study of Thessaloniki, Greece before the completion of the metro project construction. International Journal of Academic Research, 4, 136-143.

Kaufman, D. A., \& Cloutier, N. R. (2006). The impact of small brownfields and greenspaces on residential property values. The Journal of Real Estate Finance and Economics, 33(1), 1930. https://doi.org/10.1007/s11146-006-8272-7

Ki, C. O., \& Jayantha, W. M. (2010). The effects of urban redevelopment on neighbourhood housing prices. International Journal of Urban Sciences, 14(3), 276-294. https://doi.org/10.1080/12265934.2010.9693685

Kiel, K. A. (2017). Environmental contamination and house values. In J. I. Carruthers, \& B. Mundy (Eds.), Environmental Valuation (pp. 139-164). Routledge. https://doi.org/10.4324/9781351158961

Lee, C.-c., Liang, C.-M., \& Chen, C.-Y. (2017). The impact of urban renewal on neighborhood housing prices in Taipei: an application of the difference-in-difference method. Journal of Housing and the Built Environment, 32(3), 407-428. https://doi.org/10.1007/s10901-016-9518-1

Liang, C.-M., Lee, C.-C., \& Yong, L.-R. (2020). Impacts of urban renewal on neighborhood housing prices: predicting response to psychological effects. Journal of Housing and the Built Environment, 35(1), 191-213. https://doi.org/10.1007/s10901-019-09673-z
Liu, Y., Hao, P., van Oort, F., Geertman, S., \& Lin, Y. (2015). The effects of urban redevelopment on housing prices in Shenzhen [Conference presentation]. 14th International Conference on Computers in Urban Planning and Management (CUPUM 2015), Massachusetts Institute of Technology, Cambridge, MA.

Malik, S., Roosli, R., \& Tariq, F. (2020). Investigation of informal housing challenges and issues: experiences from slum and squatter of Lahore. Journal of Housing and the Built Environment, 35, 143-170. https://doi.org/10.1007/s10901-019-09669-9

McCord, J., McCord, M., McCluskey, W., Davis, P. T., McIlhatton, D., \& Haran, M. (2014). Effect of public green space on residential property values in Belfast metropolitan area. Journal of Financial Management of Property and Construction, 19(2), 117-137. https://doi.org/10.1108/JFMPC-04-2013-0008

Muhammad, I. (2017). Disamenity impact of Nala Lai (open sewer) on house rent in Rawalpindi city. Environmental Economics and Policy Studies, 19(1), 77-97. https://doi.org/10.1007/s10018-015-0136-z

Mukhija, V. (2002). An analytical framework for urban upgrading: property rights, property values and physical attributes. Habitat International, 26(4), 553-570. https://doi.org/10.1016/S0197-3975(02)00019-X

Newell, T. A. (2010). Development and neighborhood revitalization: the effects of residential investment on property values in Durham, NC. Michigan Journal of Business, 3(2), 97-120.

Nijman, J. (2008). Against the odds: slum rehabilitation in neoliberal Mumbai. Cities, 25(2), 73-85. https://doi.org/10.1016/j.cities.2008.01.003

Palmquist, R. B. (1984). Estimating the demand for the characteristics of housing. The Review of Economics and Statistics, 66(3), 394-404. https://doi.org/10.2307/1924995

Park, J. H., Lee, D. K., Park, C., Kim, H. G., Jung, T. Y., \& Kim, S. (2017). Park accessibility impacts housing prices in Seoul. Sustainability, 9(2), 185. https://doi.org/10.3390/su9020185

Patel, K. (2013). A successful slum upgrade in Durban: a case of formal change and informal continuity. Habitat International, 40, 211-217. https://doi.org/10.1016/j.habitatint.2013.05.005

Pope, D. G., \& Pope, J. C. (2012). Crime and property values: evidence from the 1990s crime drop. Regional Science and Urban Economics, 42(1), 177-188.

https://doi.org/10.1016/j.regsciurbeco.2011.08.008

Riddell, K. (2016). Islam and the securitisation of population policies: muslim states and sustainability. Taylor \& Francis. https://doi.org/10.4324/9781315589954

Rosen, S. (1974). Hedonic prices and implicit markets: product differentiation in pure competition. Journal of Political Economy, 82(1), 34-55. https://doi.org/10.1086/260169

Rosenthal, S. S., \& Helsley, R. W. (1994). Redevelopment and the urban land price gradient. Journal of Urban Economics, 35(2), 182-200. https://doi.org/10.1006/juec.1994.1012

Shukur, F., Othman, N., \& Nawawi, A. H. (2012). The values of parks to the house residents. Procedia - Social and Behavioral Sciences, 49, 350-359.

https://doi.org/10.1016/j.sbspro.2012.07.033

Simons, R., Quercia, R., \& Levin, I. (1998). The value impact of new residential construction and neighborhood disinvestment on residential sales price. Journal of Real Estate Research, 15(2), 147-161. https://doi.org/10.1080/10835547.1998.12090921

Trojanek, R., \& Gluszak, M. (2018). Spatial and time effect of subway on property prices. Journal of Housing and the Built Environment, 33(2), 359-384. https://doi.org/10.1007/s10901-017-9569-y 
Tse, R. Y., \& Love, P. E. (2000). Measuring residential property values in Hong Kong. Property Management, 18(5), 366-374. https://doi.org/10.1108/02637470010360669

Xiao, Y. (2017). Hedonic housing price theory review. In Urban morphology and housing market (pp. 11-40). Springer. https://doi.org/10.1007/978-981-10-2762-8_2

Yang, L., Zhou, J., Shyr, O. F., \& Huo, D. (2019). Does bus accessibility affect property prices? Cities, 84, 56-65. https://doi.org/10.1016/j.cities.2018.07.005

Zabel, J. E., \& Guignet, D. (2012). A hedonic analysis of the impact of LUST sites on house prices. Resource and Energy Economics, 34(4), 549-564.

https://doi.org/10.1016/j.reseneeco.2012.05.006
Zahirovich-Herbert, V., \& Gibler, K. M. (2014). The effect of new residential construction on housing prices. Journal of Housing Economics, 26, 1-18. https://doi.org/10.1016/j.jhe.2014.06.003 Zawadzki, S. J., Mainzer, S., McLaughlin, R. A., \& Luloff, A. E. (2017). Close, but not too close: landmarks and their influence on housing values. Land Use Policy, 62, 351-360. https://doi.org/10.1016/j.landusepol.2017.01.004

Zhang, Y., Zheng, S., Song, Y., \& Zhong, Y. (2016). The spillover effect of urban village removal on nearby home values in Beijing. Growth and Change, 47(1), 9-31. https://doi.org/10.1111/grow.12122

Zheng, X., Li, J.-x., Zheng, L., \& Lv, J. (2020). Multi-owned property, urban renewal and neighborhood property value externalities: revisiting the Hong Kong case. Cities, 107, 102915. https://doi.org/10.1016/j.cities.2020.102915 